Kracke, R. R. (1931). Amer. J. clin. Path., 1, 385.

- (1934). J. Amer. med. Ass., 102, 1960.

and Parker, F. P. (1934). J. Lab. clin. Med., 19, 799.

Norris, J. C. (1936). Ibid., 22, 125.

Plum, P. (1937). Clinical and Experimental Investigations in Agranulocytosis. Busck, Copenhagen.

Rawls, W. B. (1944). N.Y. St. J. Med., 44, 626

Shapiro, S., and Lehman, L. (1936). Amer. J. med. Sci., 192, 705.

Vitug, W., Chavez, A., and Austria, G. F. (1935). J. Philipp. I. med. Ass., $15,464$.

Watkins, C. H. (1933). Proc. Mayo Clin., 8, 713. Whitby, L. E. H., and Britton, C. J. C. (1950). Disorders of the Blood.
6th ed. Churchill, London.

\section{Familial Paget's Disease of Bone}

It is not generally realized that Paget's disease of bone may be familial, although this fact is mentioned in most reviews of the subject. There are at least 77 instances in the literature in which more than one member of a family suffers from this disease, and in over one-third of these more than one generation is involved. Dickson et al. (1945) reported the presence of the disease in six relatives, four generations being affected, and also in identical twins of another family. Paget's disease of bone in identical twins has also been noted by Martin (1947) and by Aschner and her colleagues (1952), although the diagnosis in one of the latter twins is very uncertain. Families with four members affected have been described on three occasions (van Bogaert, 1933; Hanke, 1935 ; Gutman and Kasabach, 1936), and with three members affected, 14 times. The family reported by Camurati (1922) and sometimes quoted in this context does not appear in fact to have suffered from Paget's disease.

A patient with Paget's disease recently treated in this hospital was found to have two brothers and two sisters who had the same condition. The case histories of 51 other patients with osteitis deformans who were treated in this hospital in the five years 1947-51 were then reviewed; a family history of the disease had been noted in three instances; in one case two relatives and in the other two cases one relative had also been afflicted by the condition.

\section{FIRST FAMILY}

Case 1.-Mr. F. R. died recently at the age of 76 . He had spent the previous few years in hospital and was enfeebled by most extensive osteitis deformans.

Case 2.-Mrs. A. S., sister of Mr. F. R., died at the age of 63. Bowing of her legs was apparent at the age of 51, and a clinical diagnosis of Paget's disease was confirmed by radiography at the age of 56 .

Case 3.-Mr. E. R., brother of Mr. F. R., aged 71, is in parttime employment as a labourer and is free of symptoms. His right tibia is somewhat bowed and has an irregular anterior border ; a radiograph of this bone showed thickening of the cortex on the anterior aspect, the changes being suggestive of early Paget's disease. This man's serum alkaline phosphatase was slightly raised at $15 \mathrm{King}$-Armstrong units.

Case 4.-Mrs. A. T., sister of the above, aged 69, first noticed bowing of her legs over twelve years ago. She has advanced Paget's disease with involvement of the skull, spine, thoracic cage, and left leg; recently a sixth cranial nerve palsy has developed.

Case 5.-Mrs. R. T., sister of the above, aged 67, has been a patient in a ward for the chronic sick for over three years. She has extensive advanced Paget's disease and can walk only with assistance.

The only other sibling, a sister, died at the age of 64 and did not, so far as is known, suffer from this condition; the parents were not blood relations, and from the descriptions given by their children they do not appear to have shown any of the obvious deformities produced by Paget's disease, nor was this disease mentioned on their death certificates. Thirteen members of the third generation of this family, with ages ranging from 30 to 58 , have been contacted and do not complain of any deformity; the three other members of this generation cannot be traced.

\section{SECOND FAMILY}

Case 1.-Mrs. M. R. began to develop the typical deformities of the legs and head at the age of 50 . She later developed deafness and blindness, the latter being due to macular and peripapillary choroidal sclerosis, and finally died at the age of 68 with extensive Paget's disease.

Case 2.-Mrs. J. K., the elder sister of Case 1, also showed deformities at about the age of 50, and also developed deafness and blindness before her death.

Case 3.-Mrs. C. H., the youngest sister of the family, noticed a painful swelling of the right tibia at the age of 46 following a minor injury. Four year later, swelling and discomfort having recurred, a diagnosis of localized Paget's disease of the tibia was made. Recently at the age of 55 the right lower leg showed the typical anterior bowing with an increase in the temperature of the overlying skin. Radiographs confirmed the presence of Paget's disease in the tibia and demonstrated early changes of the disease in the pelvis and one lumbar vertebra. The serum alkaline phosphatase was $41 \mathrm{~K}$. $-\mathrm{A}$. units.

Three other siblings died at the age of 30 or less, one died of carcinoma at the age of 49 , and the eighth, a sister, now aged 58, is free of any sign of the disease, as are eight children of the affected sisters, with ages from 25 to 50 .

\section{THIRD AND Fourth FAMILIES}

A man aged 64 developed aching of the legs and lower back at the age of 59 and was found to have osteitis deformans of the skull, pelvis, left femur, and lumbar vertebrae. An elder sister died of Paget's disease at the age of 66 .

A man aged 71 with typical advanced generalized Paget's disease reported that his father had bow legs for a few years before his death at the age of 80 .

\section{Incidence of Familial Paget's Disease}

Dickson and his colleagues (1945) found a family history of the disease in 16 out of 366 cases $(4.4 \%)$, Gutman and Kasabach (1936) in 4 out of $115(3.5 \%)$, and Locke (1943) in 10 out of 48 cases (20.8\%). Da Costa et al. (1915), reviewing all cases of Paget's disease reported up to that time, noted a familial incidence in $7 \%$.

The incidence in the present series is 4 out of 52 -that is, $7.7 \%$. From the notes of many of the patients it would seem unlikely that any close inquiries into the family histories had been made, and it is possible that a higher incidence of familial Paget's disease might have been found. The other fact which makes it difficult to estimate the true incidence is that many cases are symptomless (up to $27 \%$ of some recent large series), the diagnosis being made only when radiographs are taken for the investigation of other complaints.

There can be little doubt that this familial incidence is not coincidental ; Montagu (1949) has suggested that the predisposition to the disease may be transmitted as an incompletely dominant gene carried on an X-chromosome.

My thanks for permission to publish details concerning patients who had been under their care are due to Professor Sir James Paterson Ross, Dr. Bertram Jones, Dr. K. Kropac, Mr. I. G. Williams, and Dr. A. W. Spence, who also gave helpful advice.

H.-J. B. Galbraith, M.D., M.R.C.P., Medical Chief Assistant, St. Bartholomew's Hospital, London.

\section{REFERENCES}

Aschner, B. M., Hurst, L. A., and Roizin, L. (1952). Acta genet. med., Roma, 1, 67.

Camurati, M. (1922). Chir. Organi Mov., 6, 662

Da Costa, J. C.. Funk, E. H., Bergheim, O., and Hawk, P. B. (1915). Publ. Jefferson med. Coll.. 6, 1.

Dickson, D. D., Camp, J. D., and Ghormley, R. K. (1945). Radiology, 44. 449.

Gutman, A. B., and Kasabach, H. (1936). Amer. J. med. Sci., 191, 361 Hanke, H. (1935). Dtsch. Z. Chir., 245, 641.

Locke, E. A. (1943). Oxford Medicine, 4, 426. Oxford University Press, New York.

Martin, E. (1947). Helv. med. Acta, 14, 319.

Montagu, M. F. A. (1949). Amer. J. hum. Genet.. 1. 94

van Bogaert, L. (1933). Z. ges. Neurol. Psychiat., 147, 327. 